\title{
Thriving on Challenge: Examining One Teacher's View on Sources of Support for Motivation and Well-Being
}

\author{
Nancy E. Perry, Charlotte A. Brenner \\ University of British Columbia \\ Rebecca J. Collie \\ University of New South Wales \\ Gigi Hofer \\ University of British Columbia
}

\begin{abstract}
Alarmingly high rates of teacher attrition exist in contexts designed for students with considerable needs, such as in alternative education programs serving marginalized youth. Research has linked teachers' levels of motivation and well-being to their effectiveness and retention. Consequently, we explore what distinguishes teachers who thrive in contexts others find taxing. Specifically, we investigate whether and how their motivation and well-being support their teaching effectiveness. As part of a larger case study of an alternative education program for youth who haven't found success in mainstream schools, this article reports a semi-structured interview asking whether and how one teacher's perceived autonomy, belonging, and competence support other facets of his motivation (e.g., teaching efficacy) and his well-being (i.e., constructive responses to potentially stressful events.) Plentiful evidence was found to link our researcher-derived constructs from selfdetermination theory to the teacher's professional experiences in general, and to his work with youth in particular, indicating that our conceptual framework is an authentic representation of his experience. Implications for theory and research are discussed.
\end{abstract}


Teacher retention is a major challenge in education, especially in the field of special education and in alternative settings that serve youth with significant needs (Castro, Kelly, \& Shih, 2010; McLeskey, Tyler, \& Flippin, 2004). Research indicates teacher motivation and well-being is linked to teacher retention and effectiveness (Duckworth, Quinn, \& Seligman, 2009; Klassen, Perry, \& Frenzel, 2012; Klusmann, Kunter, Trautwein, Lüdtke, \& Baumert, 2008). Given the economic and social costs of teacher attrition (Darling-Hammond, 2003), investigations about what distinguishes teachers who thrive in challenging teaching contexts-what factors sustain and retain them-should attend to constructs associated with motivation and well-being.

Studies have demonstrated relationships between teachers' levels of motivation and their well-being, effectiveness, and the likelihood of their remaining in the teaching profession (Duckworth et al., 2009; Klassen et al., 2012; Klusmann et al., 2008). One explanation for these relationships is that teachers who report higher levels of motivation are more resilient to the challenges they face within their profession. Such findings provide further reason to more thoroughly examine influences on teachers' motivation and well-being in order to identify whether and how teachers' motivational experiences and feelings of well-being influence their commitment to, engagement in, and efficacy for teaching. Toward this end, we developed an interview protocol to facilitate the identification and examination of factors that enable teachers to thrive in teaching positions considered to be extremely challenging and stressful. In the context of a larger study focused on promoting positive outcomes for children and youth who struggle in school, we used this protocol to examine how one teacher's motivation and well-being supports his perceived effectiveness at work.

\section{Theoretical and Research Perspectives}

Our teacher interview protocol specifically focuses on how teachers' sense of selfdetermination (i.e., perceived autonomy, belonging, and competence) supports their professional motivation (i.e., enhanced efficacy, engagement, and commitment) and wellbeing (i.e., reduced stress and exhaustion).

\section{Teacher Motivation}

In our research, teachers' professional motivation is operationalized in terms of teaching efficacy, commitment, and engagement. Teaching efficacy is derived from the notion of self-efficacy (Bandura, 1997) and reflects teachers' beliefs in their ability to positively impact student learning (Tschannen-Moran \& Woolfolk Hoy, 2001). It is related to and influenced by teachers' general sense of competence (e.g., "I am good at my job"), but is future oriented (i.e., "I have potential to make a difference for particular students in particular contexts"). Within the profession of teaching, high levels of teaching efficacy have been linked to positive outcomes for teachers, such as effective classroom management routines (Tschannen-Moran \& Woolfolk Hoy, 2001), work engagement (Schaufeli \& Bakker, 2004), commitment to teaching (Canrinus, HelmsLorenz, Beijaard, Biutink, \& Hofman, 2012), and the choice of mastery goals for teaching (Cho \& Shim, 2013). Also, research indicates student benefits (e.g., increased motivation and achievement) are associated with their teachers' having a strong sense of 
efficacy about teaching (Ross, Hogaboam-Gray, \& Hannay, 2001; Roth, Assor, KanatMaymon, \& Kaplan, 2007; Woolfolk Hoy \& Davis, 2006).

Self-efficacy is among a list of personal attributes that characterize resilient teachers (Castro et al., 2010). Psychological resilience is defined as the "ability to adjust to varied situations and increase one's competence in the face of adverse conditions" (Bobek, 2002 , p. 202). It is evidenced in individuals who are able to successfully navigate themselves through difficult situations using effective coping mechanisms (Block \& Block, 1980).

Commitment refers to teachers' satisfaction with their career choice - their belief that teaching is the right profession for them. Associated with teaching efficacy, teachers' perceived feelings of commitment may protect them against the negative effects of jobrelated stress (Chan, Lau, Nie, Lim, \& Hogan, 2008; Jepson \& Forrest, 2006). Engagement is defined as a state of mind characterized by vigour, dedication, and absorption (Klassen et al., 2009). It reflects experiences of positive affect during teaching (e.g., the satisfaction that comes from finally connecting with students who are difficult to reach). Engaged teachers report experiencing high levels of energy when they teach, feel dedicated to and enthusiastic about their work, and report fewer symptoms of stress and burnout (Hakanen, Bakker, \& Schaufeli, 2006). Whereas commitment reflects teachers' long-term view of themselves in the profession, engagement reflects their more immediate experience of motivation in the moment-to-moment of teaching. Both commitment and engagement are associated with teacher retention (Billingsley \& Cross, 1992) and are characteristic of resilient teachers who experience personal satisfaction and enjoyment while teaching, even in very difficult circumstances (Castro et al., 2010; Williams, 2003).

\section{Teacher Well-Being}

We operationalize teachers' well-being in terms of their experience of stress and exhaustion. Teaching is considered to be a high-stress occupation (Chaplain, 2008; Kyriacou, 2001). Stress is reflected in negative emotions teachers experience as a result of doing their work (Kyriacou, 2001). The experience of stress is inversely related to selfefficacy (e.g., Collie, Shapka, \& Perry, 2012), commitment (e.g., Klassen \& Chiu, 2011), and engagement (e.g., Hakanen et al., 2006), and positively related to burnout, or loss of enthusiasm and idealism for one's work (Matheny, Gfroerer, \& Harris, 2000; McCarthy, Lambert, O'Donnell, \& Melendres, 2009), and to teacher attrition (e.g., Gersten, Keating, Yovanoff, \& Harniss, 2001). Exhaustion is a core element of burnout (Chang, 2009). Teachers who experience emotional exhaustion are at risk for dropping out of the profession or, if they stay, for creating learning environments of poor quality that can have harmful effects on students (Jennings \& Greenberg, 2009; Klassen et al., 2012). Key sources of stress and exhaustion for teachers include difficulties with student behaviour and classroom management, workload, and perceived lack of support from colleagues and school administrators (Klassen \& Chiu, 2010; Kyriacou, 2001).

Given the debilitating effects of stress and exhaustion on teachers and the implications of teacher retention and effectiveness, it behooves educational researchers and school system personnel who support teachers to further understand conditions that allow teachers to thrive within their professions, and to find ways to ameliorate teachers' negative 
experience of stress and exhaustion. Nieto (2009) describes thriving in the context of teaching as teachers': (a) feelings of efficacy, (b) ability to form positive connections with students, and (c) commitment and engagement within their work. Adding to Nieto's definition, we propose that teachers who thrive also experience manageable levels of stress and heightened levels of positive emotions while engaging in their work.

\section{Self-Determination}

Self-determination theory (SDT), which is a theory of motivation and well-being, proposes humans are naturally driven to seek personal growth and fulfillment (Deci \& Ryan, 2002). From a SDT perspective, growth occurs through fulfillment of three basic psychological needs that support optimal functioning: autonomy, belonging, and competence. When these psychological needs are met, intrinsic motivation is supported, resulting in increased levels of adaptive functioning (e.g., engaging in challenging tasks, fully utilizing skills), prosocial behaviour, self-esteem, personal well-being, and optimal functioning (Deci \& Ryan, 1985b, 1991; Ryan \& Deci, 2000, 2002) and decreased depressive symptoms (Van Petegem, Beyers, Vansteenkiste, \& Soenens, 2012). SDT research indicates that perceived feelings of autonomy and competence provide the foundation for psychological well-being (Sheldon, Ryan, \& Reis, 1996). For example, Sheldon et al. examined the influence of self-determination (SD) on general well-being and found that individuals who reported higher levels of perceived competence and autonomy reported greater feelings of well-being across time.

Autonomy refers to the degree to which individuals perceive they can choose their actions as opposed to feeling pressured or controlled by factors external to them. Individuals who are self-determined perceive they are agents or volitional initiators of their own actions (Grolnick, Gurland, Jacob, \& Decourcey, 2002). Autonomy-supportive work environments empower employees to make choices and exercise freedom in carrying out work tasks (Klassen et al., 2012). Roth et al. (2007) suggest teachers who express high levels of autonomy may be more resilient to external pressures (e.g., external achievement measures) and more likely to provide opportunities for students to develop autonomous behaviours and engage in deep learning tasks. Relatedness, or belonging, refers to the extent to which people feel connected, part of a group, and able to form close, meaningful relationships (Deci \& Ryan, 2002). Students as well as colleagues support teachers' sense of belonging in the workplace, and teachers use their relationships with students as a measure of their efficacy (Klassen et al., 2012). Competence is reflected in individuals' perceptions that they are doing a good job or achieving desired outcomes (Taylor \& Ntoumanis 2007). Together, perceived autonomy and belonging promote a sense of competence.

Research in a wide range of workplaces links the satisfaction of these basic needs with successful performance (e.g., Parker, Jimmieson, \& Amiot, 2013), increased motivation (e.g., Lynch, Plant, \& Ryan, 2005; Taylor, Ntoumanis, \& Standage, 2008), well-being (e.g., Klassen et al., 2012), engagement (e.g., Deci et al., 2001), and job satisfaction (e.g., Ilardi, Leone, Kasser, \& Ryan, 1993), as well as decreased stress (e.g., Klassen et al., 2012) and burnout (e.g., Van den Broeck, Vansteenkiste, De Witte, \& Lens, 2008). Recent research also indicates the implications of meeting these needs are similar 
for teachers (e.g., Klassen et al., 2012). Moreover, evidence suggests the facilitation of teachers" "self-determined" motivation to engage in their work positively influences their students' SD (Taylor \& Ntoumanis, 2007). As part of our larger study of alternative education programs for struggling youth, we are examining relationships among teachers' SD, their teaching practices, and students' SD (see Hofer \& Perry, 2012).

Although SDT studies have been conducted in a wide range of contexts (schools, athletic contexts, various workplaces) and with diverse samples (children, youth, adults), few studies have included teachers' own descriptions of SD constructs or have been conducted within alternative education settings. Like much of the motivation literature, studies of SD have relied mainly on survey self-report data that make use of researcherderived representations of constructs associated with motivation and well-being (Urdan \& Turner, 2005). While useful, these questionnaires frame the constructs of autonomy, competence, and relatedness from researchers' rather than participants' points of view, an approach that may limit teachers' responses to fit within the perimeters of predetermined constructs. In order to yield practical, meaningful results, we believe research should include the voices of practitioners and be based on their everyday experiences in naturalistic contexts (e.g., Strauss \& Corbin, 1994). To this end, our protocol is designed to: (a) elicit teachers' descriptions of what motivates and sustains them in their work, and (b) examine the language teachers use to describe their experiences in relation to constructs identified in theories and related research (e.g., SD, self-efficacy). Through this process, the integrity of practitioners' perspectives is maintained and then used to confirm researchers' constructs (Strauss \& Corbin, 1994), facilitating the advancement of both theory and construct consensus in research on SDT.

\section{Our Study}

\section{Context and Design}

Our larger study examining how to support positive outcomes for at-risk youth asks: "What do teachers do and say to promote SD in their students?" and "How can conditions be created that motivate and engage students in school?" We started this larger study in one alternative education program (AEP), largely as means of testing and refining protocols for our qualitative case study research. From our initial observations of the teacher working in this program and our reading of relevant research (e.g., Castro et al., 2010; Klassen et al., 2012; Taylor \& Ntoumanis, 2007), we concluded our research purpose might be enriched by focusing on teachers' motivation and well-being (i.e., given that teachers' and students' motivation and achievement are inextricably linked). Therefore, we added an investigation of teachers' motivation and well-being to our research asking three more questions:

(a) What experiences contribute to teachers' perceptions of autonomy, belonging, and competence?

(b) Do teachers' perceive that fulfillment of these SD needs supports other aspects of their motivation (i.e., self-efficacy, engagement, and commitment) and well-being (low levels of stress and of exhaustion)? 
(c) How do teachers perceive that their motivation and sense of well-being influence their educational practices and the experiences they provide for their students?

Here we report data from our interview with the teacher in the initial site to begin to address the first two questions. Specifically, we report data from our interview with Brian, ${ }^{1}$ who we judge is thriving in his work with highly vulnerable youth.

Students who attend Brian's program are youth (12-19 years of age) who have not experienced success in the mainstream school system. They have a history of academic difficulties, which makes them vulnerable to numerous negative outcomes including school disengagement and drop-out (Battin-Pearson et al., 2000; Christenson \& Thurlow, 2004; Henry, Knight, \& Thornberry, 2012). All students in Brian's program are either in the care of a social worker or on probation. At the time of our study, many of Brian's students resided in foster care or group homes, had histories of drugs and/or alcohol abuse, few positive role models, and significant barriers to employment. On average, the program enrolls 20 students with 6 to 12 students attending on any given day.

Case study analyses, with their emphasis on providing an in-depth understanding of an entity situated in a specific context, are particularly appropriate for our research purposes (Butler, 2011). They allow us to: (a) pursue how and why research questions involving multidimensional phenomena in real-world settings, (b) investigate relationships between individuals and social phenomena as they manifest in genuine activities, (c) explore and define emerging theoretical constructs, (d) expand understandings from previous research, and (e) link researcher-derived constructs of SD needs and teacher well-being to teachers' perceptions and actual experience of these constructs (Butler, 2011; Denzin \& Lincoln, 2005; Gibbert, Ruigrok, \& Wicki, 2008; Yin, 2003).

\section{Participant}

Brian is the sole teacher in an AEP in a large urban school district in Western Canada. He has been in his current position for six years. This is Brian's first teaching position, although he has worked with struggling youth in other contexts for more than 20 years (e.g., youth shelters and group homes, detention and detox centers, remedial camps). Brian's program is housed outside of a traditional school setting, located in a strip mall in a low-socioeconomic status (SES) urban neighborhood. Other adults assigned to the program include a full-time teaching aide and specialized counsellors (i.e., having specialized training in addiction and mental health issues). Brian is also in regular contact with social workers and probation officers assigned to particular students. These other adults were not participants in the study.

\section{Interview Protocol}

Our semi-structured interview protocol makes use of open-ended questions that address five broad topics: (a) teaching and related history (e.g., What made you choose to work with struggling youth? What keeps you working with these youth?); (b) job satisfaction (e.g., What do you enjoy about your current position? What do you perceive

\footnotetext{
${ }^{1}$ Pseudonym
} 
are the benefits of teaching in this environment? What are some challenges?); (c) sources of motivation (e.g., How do you measure success in this position? What experiences make you feel effective?); (d) self-determination (e.g., Tell me about your relationships with students. How do these affect your sense of teaching efficacy, enjoyment of teaching, and belief that you can make a difference in their lives?); and (e) sources of well-being (e.g., What qualities do you have as a teacher and person that sustain you in your work? How do you cope with the challenges in your work?). These questions are designed as conversation starters and teachers are encouraged to direct the conversation and express experiences in their own terms. Consistent with the semi-structured nature of the interview protocol, Brian led the conversation during his interview; and he discussed content related to many of the questions without prompting. The researchers were also free to ask questions that occurred to them as a result of Brian's comments (e.g., Is there a characteristic about [colleagues who stay in the profession] that is similar or something about them that you notice?).

Brian's interview spanned 77 minutes. Because our interview protocol was being used for the first time, two researchers conducted this interview. The researchers met Brian in his workplace at a mutually agreed-upon time (mid-afternoon after most students had left for the day). One of the researchers led with the interview topics; however, the other researcher also asked questions for clarification and/or elaboration. The context (i.e., sitting at a kitchen table) and conversation were informal, and Brian appeared comfortable and forthcoming in his responses. The interview was audio-recorded and later transcribed for purpose of analyses.

\section{Coding}

Table 1 (below) lists the conceptual categories we identified prior to our data collection. For each category, an operational definition is provided along with links to supporting literature.

The two researchers who conducted the interview also coded the interview transcript, first separately, then together. Specifically, each researcher examined the transcript and identified examples from Brian's transcript that either corresponded to conceptual categories or pointed to additional categories. The researchers then individually recorded examples in a template. After their independent analyses the researchers met and, together, reviewed all examples of codes. Examples of codes drawn from the interviews were then presented to three additional researchers familiar with SDT. After reviewing the data, consensual validation was reached-all researchers agreed on the codes and themes used to represent the examples (see Table 2 for examples matched to codes). 
Table 1.

\section{Conceptual Categories Used to Assess Teachers' Motivation, Including Self-Determination and Well-Being}

\begin{tabular}{|c|c|c|}
\hline $\begin{array}{l}\text { Motivational } \\
\text { Attributes }\end{array}$ & Definition & Literature to Support \\
\hline \multirow[t]{2}{*}{ Autonomy } & $\begin{array}{l}\text { Being the source of one's behaviour and achieving congruence between one's activity and one's } \\
\text { sense of self-perception of acting with integrity. }\end{array}$ & $\begin{array}{l}\text { Ryan \& Deci, 2002; Taylor \& } \\
\text { Ntoumanis } 2007\end{array}$ \\
\hline & $\begin{array}{l}\text { Autonomy-supportive workplaces encourage employee initiation and empowerment-offer } \\
\text { choice and freedom to carry out work tasks. }\end{array}$ & Klassen et al., 2012 \\
\hline \multirow[t]{2}{*}{ Belonging } & $\begin{array}{l}\text { Connecting with others (e.g., colleagues or students in the context of teaching). Perception of } \\
\text { being a group member, developing close relationships. }\end{array}$ & $\begin{array}{l}\text { Klassen et al., 2012; Ryan \& Deci, } \\
\text { 2002; Taylor \& Ntoumanis, } 2007\end{array}$ \\
\hline & $\begin{array}{l}\text { This is generally subsumed under autonomy support (i.e., "when people feel autonomous, they } \\
\text { will often also feel relatedness for they experience the psychological freedom that allows them to } \\
\text { pursue meaningful connections with others" (Ryan \& Deci, 2011, p. 54). }\end{array}$ & $\begin{array}{l}\text { Deci, Eghrari, Patrick, \& Leone, } \\
\text { 1994; Ryan \& Deci, } 2011\end{array}$ \\
\hline Competence & $\begin{array}{l}\text { Sense that one is having an effect on the environment and achieving desired outcomes. Feeling } \\
\text { effective. }\end{array}$ & $\begin{array}{l}\text { Klassen et al., } 2012 ; \text { Taylor \& } \\
\text { Ntoumanis , } 2007\end{array}$ \\
\hline \multirow[t]{3}{*}{ Efficacy } & Belief in one's ability to have a positive impact. Belief in one's ability to be successful. & \\
\hline & $\begin{array}{l}\text { Supports for the fulfillment of efficacy include: the availability of resources, opportunities for } \\
\text { mastery experiences, support from colleagues, community support, and satisfaction with } \\
\text { performance. }\end{array}$ & $\begin{array}{l}\text { Tschannen-Moran \& Woolfolk Hoy, } \\
2001\end{array}$ \\
\hline & $\begin{array}{l}\text { The distinction we make between competence and self-efficacy is that competence is a judgment } \\
\text { that you are or have been effective (e.g., "I'm good at what I do."), whereas efficacy is a } \\
\text { prediction about potential to succeed or be effective (e.g., "I think I can help this student in the } \\
\text { future"). Current and past successes likely influence judgments about future efficacy. }\end{array}$ & $\begin{array}{l}\text { Klassen, Tze, Betts, \& Gordon, } \\
\text { 2011; Tschannen-Moran \& Woolfolk } \\
\text { Hoy, } 2007\end{array}$ \\
\hline Engagement & $\begin{array}{l}\text { Enjoyment of teaching. Perception that teaching is positive and fulfilling. Experience of vigour, } \\
\text { dedication, absorption during teaching. Engaged teachers are energetic and effective, able to } \\
\text { deal with complex demands. Student misbehaviour can interfere with teachers' engagement. } \\
\text { Autonomy can protect engagement. }\end{array}$ & $\begin{array}{l}\text { Klassen et al., 2012; Schaufeli, } \\
\text { Bakker, \& Salanova, } 2006\end{array}$ \\
\hline
\end{tabular}




\begin{tabular}{|c|c|c|}
\hline $\begin{array}{l}\text { Motivational } \\
\text { Attributes }\end{array}$ & Definition & Literature to Support \\
\hline \multirow[t]{2}{*}{ Commitment } & Refers to satisfaction with a career choice-teaching is the right profession for me. & \\
\hline & $\begin{array}{l}\text { Teacher commitment can be promoted by administrative support (i.e., support for student } \\
\text { discipline, instructional methods, curriculum, and working conditions). Employee commitment in } \\
\text { general can be supported by the organization's support for employee involvement, growth and } \\
\text { development, recognition, work life balance, health and safety, and employee well-being. }\end{array}$ & $\begin{array}{l}\text { Grawitch, Trares, \& Kohler, 2007; } \\
\text { Tickle, Chang, \& Kim, } 2011\end{array}$ \\
\hline \multirow[t]{2}{*}{ Resilience } & $\begin{array}{l}\text { The "ability to adjust to varied situations and increase one's competence in the face of adverse } \\
\text { conditions." }\end{array}$ & Bobek, 2002 (p. 202) \\
\hline & $\begin{array}{l}\text { Characterized by individuals' effective use of coping mechanisms to guide themselves through } \\
\text { difficult situations. }\end{array}$ & Block \& Block, 1980 \\
\hline \multirow[t]{2}{*}{ Thriving } & The experience of feeling efficacious, connected to students, and engaged while teaching. & \\
\hline & $\begin{array}{l}\text { Characterized by high levels of teaching engagement and teachers' belief that they can positively } \\
\text { impact student outcomes. }\end{array}$ & Nieto, 2009 \\
\hline $\begin{array}{l}\text { Well-Being } \\
\text { Attributes }\end{array}$ & Definition & Literature to Support \\
\hline \multirow[t]{2}{*}{ Stress } & Reflected in negative affect. & \\
\hline & $\begin{array}{l}\text { Sources of stress for teachers: student behaviour, classroom management, workload, perceived } \\
\text { lack of support from mentors and school administrators. }\end{array}$ & $\begin{array}{l}\text { Klassen \& Chiu, 2010; Kyriacou, } \\
2001\end{array}$ \\
\hline \multirow[t]{2}{*}{ Exhaustion } & $\begin{array}{l}\text { Characterized by negative emotions. Typically the result of prolonged stress. Manifests with } \\
\text { physical and emotional symptoms. Core element in burnout. }\end{array}$ & Klassen et al., 2012 \\
\hline & In teaching, it is associated with work overload and student misbehaviour. & Klassen et al., 2012 \\
\hline \multirow[t]{2}{*}{ Burnout } & The loss of enthusiasm and idealism for one's work. & Matheny, Gfroerer, \& Harris, 2000 \\
\hline & $\begin{array}{l}\text { Characterized by emotional exhaustion, high levels of stress, depressive symptoms, lack of } \\
\text { engagement and commitment, and depersonalization. }\end{array}$ & $\begin{array}{l}\text { Hakanen, et al., 2006; Maslach \& } \\
\text { Jackson, } 1981\end{array}$ \\
\hline
\end{tabular}

14 Exceptionality Education International, 2015, Vol. 25, No. 1 
Table 2.

Brian's Experience of Self-Determination, Motivation, and Well-Being

\begin{tabular}{|c|c|c|c|c|}
\hline Attributes & $\begin{array}{l}\text { Questions } \\
\text { (from Transcript) }\end{array}$ & Examples (from Transcript) & $\begin{array}{l}\text { Other } \\
\text { Categories }\end{array}$ & $\begin{array}{l}\text { Line } \\
\text { Numbers }\end{array}$ \\
\hline \multirow[t]{2}{*}{ Autonomy } & $\begin{array}{l}\text { What about this } \\
\text { program is a good fit } \\
\text { for you? }\end{array}$ & $\begin{array}{l}\text { You have a little more say ... [about] the direction in which you go ... just being } \\
\text { able to steer a little bit more. }\end{array}$ & & $481-495$ \\
\hline & & $\begin{array}{l}\text { I don't follow the same rules that everyone else does ... we're creative. } \\
\text { [discussion about using funds for technology] And so, we have rules, and those } \\
\text { rules have guidelines, but there's always, like, ways to work within all those } \\
\text { guidelines. }\end{array}$ & & $1203-1213$ \\
\hline \multirow[t]{3}{*}{ Belonging } & $\begin{array}{l}\text { [elaborating on what } \\
\text { keeps him working } \\
\text { with struggling } \\
\text { youth] What does it } \\
\text { mean to be "good at } \\
\text { it?" }\end{array}$ & I firmly believe you can make a connection ... I do this with all my youth. & $\begin{array}{l}\text { Competence } \\
\text { Efficacy }\end{array}$ & $189-191$ \\
\hline & $\begin{array}{l}\text { What do you enjoy } \\
\text { about your current } \\
\text { position? }\end{array}$ & $\begin{array}{l}\text { Being able to connect with the youth the way I can because of the } \\
\text { environment-I don't need some kid to give me three math sheets if he's having } \\
\text { a bad day, or if they come in high, I don't let them stick around. }\end{array}$ & Autonomy & $381-384$ \\
\hline & $\begin{array}{l}\text { What opportunities } \\
\text { do you have to } \\
\text { relate to peers and } \\
\text { colleagues? How } \\
\text { important are those } \\
\text { relationships to your } \\
\text { working life? }\end{array}$ & $\begin{array}{l}\text { Unless you work in a program like ours ... I don't really see eye to eye with a lot } \\
\text { of ... teachers ... they don't understand how I do my job ... I don't understand } \\
\text { how they do their job ... there's times where [I think] it'd be nice to be part of a } \\
\text { team, like a bigger team, but that would be in a different setting. }\end{array}$ & & $784-793$ \\
\hline Competence & $\begin{array}{l}\text { What keeps you } \\
\text { working with } \\
\text { struggling youth? }\end{array}$ & I know that I'm good at what I do ... and I like it. & & 146 \\
\hline
\end{tabular}




\begin{tabular}{|c|c|c|c|c|}
\hline Attributes & $\begin{array}{l}\text { Questions } \\
\text { (from Transcript) }\end{array}$ & Examples (from Transcript) & $\begin{array}{l}\text { Other } \\
\text { Categories }\end{array}$ & $\begin{array}{l}\text { Line } \\
\text { Numbers }\end{array}$ \\
\hline \multirow[t]{2}{*}{$\begin{array}{l}\text { Competence, } \\
\text { cont'd }\end{array}$} & $\begin{array}{l}\text { How long have you } \\
\text { been working in this } \\
\text { program? How does } \\
\text { it compare ... }\end{array}$ & $\begin{array}{l}\ldots \text { having had a lot of experience in this field and in different settings ... I've } \\
\text { always taken little pieces of what works or what doesn't work ... and then } \\
\text { having a good relationship with my colleagues, we build a good program, one } \\
\text { that meets the needs of our kids. }\end{array}$ & $\begin{array}{l}\text { Belonging } \\
\text { Efficacy }\end{array}$ & $336-339$ \\
\hline & $\begin{array}{l}\text { How do you } \\
\text { measure success in } \\
\text { this position? }\end{array}$ & $\begin{array}{l}\text { You don't ... You measure it ... one thing at a time ... based on each kid ...very } \\
\text { small increments because if you try to measure it in big ... you're going to never } \\
\text { last. }\end{array}$ & $\begin{array}{l}\text { Exhaustion } \\
\text { Stress }\end{array}$ & $518-521$ \\
\hline Efficacy & $\begin{array}{l}\text { What keeps you } \\
\text { working with } \\
\text { struggling youth? }\end{array}$ & $\begin{array}{l}\text { I have ideas of what l'd like to do and how we could ... as a system we could } \\
\text { make a difference [later he gives examples of what he'd like to do with } \\
\text { technology and goal-setting and work experience with kids as young as grade } \\
\text { 6]. }\end{array}$ & & $163-164$ \\
\hline Engagement & $\begin{array}{l}\text { How important is it } \\
\text { to you to be able to } \\
\text { make a difference? } \\
\text { Are you } \\
\text { disappointed when } \\
\text { you can't? }\end{array}$ & $\begin{array}{l}\text { I remember a kid at Covenant House ... when I was a youth worker ... we } \\
\text { would do this camping trip, and there was this hike. This kid ended up coming } \\
\text { to [back to] Covenant House [when he was] } 20,21 \text {. And he [was a] homeless } \\
\text { kid. And he sees me, and he's, like, "Brian, come here. I want to show you } \\
\text { something." He goes into his room, and he's got a picture of us standing out on } \\
\text { top of this ... hill. I was, like, jeez, ... this kid's been homeless for however } \\
\text { many years, and he's got a picture from this trip ... that was pretty cool. }\end{array}$ & & $709-718$ \\
\hline \multirow[t]{3}{*}{ Commitment } & $\begin{array}{l}\text { In 5-10 years from } \\
\text { now, where do you } \\
\text { see yourself? }\end{array}$ & Working with youth on some level. & & 1033 \\
\hline & $\begin{array}{l}\text { What keeps you } \\
\text { working with } \\
\text { strugaling vouth? }\end{array}$ & I see myself sticking with this youth ... giving them the tools at an earlier age & & $176-177$ \\
\hline & & $\begin{array}{l}\text { I want to be ... an advocate for at-risk youth ... making sure [they] get proper } \\
\text { technology literacy. }\end{array}$ & & $873-874$ \\
\hline Stress & $\begin{array}{l}\text { How do you } \\
\text { personally cope with } \\
\text { challenges in your } \\
\text { work, such as stress? }\end{array}$ & 'B' and I talk & Belonging & 457 \\
\hline
\end{tabular}




\begin{tabular}{|c|c|c|c|c|}
\hline Attributes & $\begin{array}{l}\text { Questions } \\
\text { (from Transcript) }\end{array}$ & Examples (from Transcript) & $\begin{array}{l}\text { Other } \\
\text { Categories }\end{array}$ & $\begin{array}{l}\text { Line } \\
\text { Numbers }\end{array}$ \\
\hline \multirow[t]{2}{*}{ Stress, cont'd } & & $\begin{array}{l}\text { Exercise ... that works for me ... I just don't let things get to me ... I've just } \\
\text { always been able to turn it off ... I don't need to hold on to things ... there are } \\
\text { times where I do, and then that's where the wine comes in. I'm like, "Jesus, I } \\
\text { need a glass of wine." }\end{array}$ & & $1113-1127$ \\
\hline & $\begin{array}{l}\text { Can you tell me } \\
\text { about your position? } \\
\text { What is your } \\
\text { mandate? }\end{array}$ & $\begin{array}{l}\text { [discusses diverse nature of job/job demands] Putting out six fires at once ... a } \\
\text { kid crying ... a kid needing serious mental health help ... [a student] needing } \\
\text { detox or whatever ... and you're told to focus on Science } 10 . . . \text { Definitely no } \\
\text { consistency }\end{array}$ & & $249-257$ \\
\hline \multirow[t]{3}{*}{ Exhaustion } & $\begin{array}{l}\text { How do you cope } \\
\text { with challenges in } \\
\text { your work? Do you } \\
\text { experience } \\
\text { exhaustion? }\end{array}$ & $\begin{array}{l}\text { I've had days where l've been just down ... We talk about goals all the time } \\
\text { here ... you don't always practice what you preach, right? [describes his need } \\
\text { to sit down and review his personal goals] Just having those goals ... "OK, } \\
\text { there's my focus again." }\end{array}$ & & $1159-1167$ \\
\hline & & $\begin{array}{l}\text { [Speaking about the youth in his program] So that's one of the downfalls ... the } \\
\text { constant repetition of situations, varied obviously, but very similar. }\end{array}$ & & $429-431$ \\
\hline & $\begin{array}{l}\text { What are some of } \\
\text { the challenges of } \\
\text { your position? }\end{array}$ & $\begin{array}{l}\text { We don't get a choice of who comes here. You've got, you know, K who's got a } \\
63 \text { IQ and does drugs, but then you've got Johnny over here who's in Grade } 10, \\
\text { doing really well, but [has] all these other issues. And then, you've got someone } \\
\text { else who's prostituting themselves on the street. }\end{array}$ & & $441-450$ \\
\hline \multirow[t]{2}{*}{ Frustration } & $\begin{array}{l}\text { What keeps you } \\
\text { working with } \\
\text { struggling youth? }\end{array}$ & $\begin{array}{l}\text { Yeah ... I guess what's frustrating is that some of [the youth] don't need to be } \\
\text { [here] ... if you just did a couple of things earlier, or didn't do a couple of things } \\
\text { earlier ... they'd be better off ... [they would have developed] tools at an earlier } \\
\text { age so ... [they would be] ready ... To move on or have bigger hopes and bigger } \\
\text { dreams. }\end{array}$ & & $170-180$ \\
\hline & $\begin{array}{l}\text { What is your } \\
\text { mandate? }\end{array}$ & $\begin{array}{l}\text { The district would describe one thing and the reality is another ... [describes } \\
\text { pressure to teach academics, and the reality of the needs of the students e.g., } \\
\text { suicide prevention] ... academics are the least of these kids' worries.... I } \\
\text { should be dealing with their mental health stuff [and basic living skills] ... if we } \\
\text { are to make any change in their lives. }\end{array}$ & & $260-280$ \\
\hline
\end{tabular}


Table 2, cont'd

\begin{tabular}{|c|c|c|c|c|}
\hline Attributes & $\begin{array}{l}\text { Questions } \\
\text { (from Transcript) }\end{array}$ & Examples (from Transcript) & $\begin{array}{l}\text { Other } \\
\text { Categories }\end{array}$ & $\begin{array}{l}\text { Line } \\
\text { Numbers }\end{array}$ \\
\hline \multirow[t]{3}{*}{$\begin{array}{l}\text { Frustration, } \\
\text { cont'd }\end{array}$} & $\begin{array}{l}\text { Can you tell me } \\
\text { about the position } \\
\text { you are in? }\end{array}$ & $\begin{array}{l}\text { It literally is different day to day. [Describes frustration of irregular attendance; } \\
\text { difficulties with a youth in placement] ... it was very frustrating, negative and } \\
\text { positive things happening ... one day ... you're putting out six fires at once, ... a } \\
\text { kid crying, kid needing some serious mental health help, [a student] needing } \\
\text { detox... it just varies. And then, the next day you're in here, and you're told to } \\
\text { focus in on Science } 10 \ldots \text { there's no consistency. Definitely no consistency. }\end{array}$ & & $239-257$ \\
\hline & $\begin{array}{l}\text { Do you have } \\
\text { opportunities to } \\
\text { connect with other } \\
\text { colleagues? }\end{array}$ & $\begin{array}{l}\text { [Discussing communicating with other teachers at Professional Development } \\
\text { Days] ... [other teachers will say] "I don't understand how you guys can have a } \\
\text { program that the kids only come for three hours a day" ... “I don't understand } \\
\text { how a school can run where they expect the kid to come one hour a day, ... We } \\
\text { just make our kids come."... I had to actually bite my tongue ... [we had a } \\
\text { student who was] prostituting herself out on the street, and that's why-her } \\
\text { coming to school the next day is a success. }\end{array}$ & & 817-838 \\
\hline & $\begin{array}{l}\text { Asked to elaborate } \\
\text { on ideas about how } \\
\text { to improve } \\
\text { education for at-risk } \\
\text { youth }\end{array}$ & $\begin{array}{l}\text { I was in leadership training for [school district]. Someone who was dealing with } \\
\text { the Ministry ... was explaining to us what's going on [regarding technology } \\
\text { resources], in my head I'm thinking, "Oh, this is great. You know, like, this will } \\
\text { be great for my kids,"... then, I [asked] "So, for all the haves, this works } \\
\text { awesome, but, what about the have-nots? - and [the presenter] goes, “... this } \\
\text { isn't perfect, and we're still working out some things." [I thought] ... they have } \\
\text { no clue what they're going to do with them, and it'll just be a further barrier ... } \\
\text { this technology stuff to-_for them to be left behind. }\end{array}$ & & $860-873$ \\
\hline \multirow[t]{3}{*}{ Hope } & $\begin{array}{l}\text { What does it mean } \\
\text { to be good at [your } \\
\text { job]? }\end{array}$ & $\begin{array}{l}\text { [When talking about maintaining positive, non-judgmental relationships with } \\
\text { youth] Just don't tell me the details of what you're doing because then I have to } \\
\text { report it. }\end{array}$ & Belonging & $227-228$ \\
\hline & $\begin{array}{l}\text { How do you cope } \\
\text { with [traumatic } \\
\text { negative events in } \\
\text { students' lives]? }\end{array}$ & $\begin{array}{l}\text { The next day, something great happens, and we're, like, "Okay, this was good. } \\
\text { This is why we're doing it." }\end{array}$ & Competence & $456-458$ \\
\hline & $\begin{array}{l}\text { How do you } \\
\text { measure success in } \\
\text { this position? }\end{array}$ & $\begin{array}{l}\text { You don't. You really don't. You measure it, like, one thing at a time. Yeah, you } \\
\text { measure it-like, it's based on each kid, and you measure very small } \\
\text { increments because if you try and measure it in big, you're going to never last. }\end{array}$ & & $517-520$ \\
\hline
\end{tabular}


Table 2, cont'd

\begin{tabular}{|c|c|c|c|c|}
\hline Attributes & $\begin{array}{l}\text { Questions } \\
\text { (from Transcript) }\end{array}$ & Examples (from Transcript) & $\begin{array}{l}\text { Other } \\
\text { Categories }\end{array}$ & $\begin{array}{l}\text { Line } \\
\text { Numbers }\end{array}$ \\
\hline \multirow[t]{5}{*}{ Hope, cont'd } & & $\begin{array}{l}\text { And it's not academic. It's not-you know, it's-there's no way to measure- } \\
\text { like, there's no constant, but-like, you know, l've got a young lady who's up in } \\
\text { treatment now, and it's amazing that she's up there. Like, I mean, she was in } \\
\text { terrible shape before. And so, I'm, like, that's a huge success. }\end{array}$ & & $565-570$ \\
\hline & $\begin{array}{l}\text { How does your } \\
\text { relationship with } \\
\text { students affect your } \\
\text { belief that you can } \\
\text { make a difference in } \\
\text { their lives, or does it? }\end{array}$ & $\begin{array}{l}\text { Then you see them two years later because l'd work at both places, and you're, } \\
\text { like, "Wow, this is great." And they-some of those seeds that were planted } \\
\text { earlier, you know, grew a couple of years later and stuff like that. Yeah, you } \\
\text { never know. }\end{array}$ & & $696-700$ \\
\hline & $\begin{array}{l}\text { What about your } \\
\text { relationship with the } \\
\text { youth's families? Do } \\
\text { you have } \\
\text { relationships with } \\
\text { their families? }\end{array}$ & $\begin{array}{l}\text { The unfortunate thing is that sometimes when I see the family and I know more } \\
\text { about the family, it makes me feel less likely that there's going to be success } \\
\text { because I'm just like, "Oh, my God. You've got no hope at all." }\end{array}$ & & $747-751$ \\
\hline & $\begin{array}{l}\text { What opportunities } \\
\text { do you have to } \\
\text { relate to peers and } \\
\text { colleagues? } \\
\text { How important are } \\
\text { those relationships } \\
\text { to your working life? }\end{array}$ & $\begin{array}{l}\text { Unless you work in a program like ours ... [it is difficult to] understand how I do } \\
\text { my job.... It'd be nice to be part of a team, like a bigger team, but that would be } \\
\text { in a different setting. }\end{array}$ & & $783-794$ \\
\hline & & $\begin{array}{l}\text { [If I] go to a Pro D Day for all the alternate schools, I often find that .... [that there } \\
\text { is] not a whole lot of connecting with the other staff and that...other programs } \\
\text { are, "Like, I don't understand how you guys can have a program that the kids } \\
\text { only come for three hours a day." ...I was, like, "Yeah, and that student is } \\
\text { prostituting herself out on the street, and that's why-her coming to school the } \\
\text { next day is a success." }\end{array}$ & & 799-833 \\
\hline
\end{tabular}

Note: Responses that reflected more than one category were accommodated within a separate column labeled Other Categories. 


\section{Results and Discussion}

We used evidence from Brian's transcript to link our researcher-derived constructs with his perceived experience. In particular, we focused on how: (a) Brian's self-reported experience reflected our definitions of autonomy, belonging, and competence; and (b) the fulfillment of these SD needs appeared to support other aspects of his motivation and well-being. First we present evidence that Brian experienced each of the researcherderived motivation and well-being variables. Then, we identify new categories that emerged in Brian's transcript. Finally we examine relationships among all motivation and well-being variables.

\section{Self-Determination Variables}

Autonomy. Autonomy underlies teachers' sense of empowerment (Klassen et al., 2012). Possessing a sense of autonomy enables teachers to maintain congruency between their sense of self and their actions, thereby decreasing feelings of inner conflict and leading to increased levels of well-being (Ryan \& Deci, 2000). Brian demonstrated a strong sense of autonomy. His responses to several interview questions indicated he perceived his position offered him freedom and flexibility to "choose the direction in which [he wants] to go ... steer a little bit more" (1. 481-495). For example, Brian felt free to make adjustments to the curriculum to meet the needs of students. He spoke about "making a lot of my own stuff ... because I know what works for our kids" (1. 11851187; see Table 2, Competence). His comments indicated he was aware of the program's educational mandate, and although he expressed frustration about the mandate (see Emergent Variables, Frustration, below), he did not express feeling constrained by it. He perceived he had greater control over aspects of teaching and learning than his peers in mainstream programs (e.g., "I don't follow the same rules as everyone else ... we have rules, and ... guidelines, but ... there's ... ways to work within those guidelines," 1. 1203-1213). The level of autonomy Brian experienced allowed him to use and create resources flexibly to address the specific needs of his students.

Belonging. Brian also demonstrated strong feelings of belonging or relatedness with those in his immediate work environment. In particular, he was confident in his ability to develop and maintain relationships with his students (e.g., "I firmly believe you can make a connection ... I do this with all my youth," 1. 189-191). He attributed this success to several factors: (a) his experiences as a youth (e.g., "I was a little bit along the similar line as some of these youth ... [but] with less barriers to success," 1. 208-210); (b) the autonomy the program provided (e.g., "I can [connect with the youth] because of the environment-I don't need [a student] to give me three math sheets if he's having a bad day," 1. 381-384); (c) his consistency in dealing with students (e.g., "I am consistent with every kid ... I never let a kid know I don't like [him/her]," 1. 622-627); and (d) his ability to create a home-like environment within the school, where students feel free to come and go and use the resources available. For example, Brian stated,

We're a home base for a lot of people [who work with the youth] -we have probation officers meet their kids here and everything else ... we have kids [handing 
out] resumes ... they put our phone number [and we take messages] ... (1. 310-311, 401-403).

Brian did not perceive a strong need to connect with students' families. When asked whether he had relationships with students' families, he said, "For the most part, no" (1. 735). He went on to say,

... I'll be honest with you, [not having contact] sometimes helps ... [for some youth] I don't want to connect with the family because that changes the dynamics. If the kid thinks I have a good relationship with Mom or Dad, then [s/he perceives] we're working against $[\mathrm{him} / \mathrm{her}]$... The unfortunate thing is sometimes when I see the family and I know about the family, it makes me feel less likely that there's going to be success $(1.736-741,749-752)$.

We interpret that, at least in some cases, Brian purposely avoided connections with students' families to protect his sense of efficacy and optimism for working with the youth.

Also, Brian expressed a limited sense of relatedness to teacher colleagues, especially those working in traditional settings (e.g., "they don't understand how I do my job ... I don't understand how they do their job," 1. 784-793). However, he did express appreciation for the support he received from his teaching aide, referring to him as his "work husband" (1. 457-462, see Table 2, Stress), and he described a colleague from another alternative program to whom he could talk about a "crappy day" (1. 1135-1140). Overall, it appears Brian's need for belonging was met primarily through his relationships with his students. This finding is consistent with research indicating that most teachers (i.e., kindergarten through Grade 12) value their relationships with students more than their relationships with peers (Klassen et al., 2012), which may be a feature of the unique context in which teachers work.

Competence. Finally, competence refers to teachers' experience of success - their judgment about whether they are effective at what they do (Klassen et al., 2012; Taylor \& Ntoumanis, 2007). Brian's sense of competence and confidence was apparent throughout the interview. When asked what keeps him working with struggling youth, he said, "I know I'm good at what I do ... and I like it" (1. 146). Encouraged to elaborate about what makes him "good at what [he does]," he reflected once more on his ability to relate to students (e.g., "... kids that usually put up barriers... I [am] ... able to ... break down those barriers really quickly," 147-150), but also referred to knowledge and skill that accrues from experience. For example, he said,

... having had a lot of experience in this field and in different settings ... I've always taken little pieces of what works or doesn't work ... then having a good relationship with colleagues, we build a good program, one that meets the needs of our kids (1. 336-339).

Brian's ability to select, choose, and tailor instruction and curriculum to his unique teaching and learning context is consistent with Duffy's (1997) description of highly effective teachers. Also consistent with research on effective teachers (see Brophy, 2004) are the personal attributes that Brian mentioned throughout the interview (e.g., accepting, won't judge, calm, honest with students, flexible, able to adapt). When asked how he measured success, his response indicated he is patient and able to recognize and accept 
differing forms of student success: "You measure it ... one thing at a time ... based on each kid ... very small increments, because if you try to measure it in big [increments]... you're going to never last" (1. 518-521). He also commented that much of what he sees as success in students is not school related.

\section{Motivational Variables}

Efficacy. Teachers' sense of efficacy is related to their perceived competence, but focuses on teachers' beliefs about their ability to positively impact students' lives in the future, rather than a competency judgment about what has already been achieved (Tschannen-Moran \& Woolfolk Hoy, 2001). When asked, "What keeps you working with struggling youth?" Brian revealed his efficacy for making changes that would improve his current program (e.g., "I have ideas of what I'd like to do and how ... as a system, we could make a difference ... I know where I'd like to take the program," 1. 163-164, 846849). At various points in the interview, he described specific initiatives that he would like to implement (e.g., promoting programs that would enhance technological literacy for disadvantaged youth; linking work experience with schooling). He stressed the need to implement these initiatives much earlier (e.g., "If you just did a couple of things earlier, or didn't do a couple things earlier ... they'd be better off," 1. 170-180; see Table 2 , Frustration), before students are placed in programs like his. Additionally, he indicated a desire to "teach people - teach teachers." He expressed frustration at seeing classroom teachers struggle, mostly unsuccessfully, with what he perceived were manageable problems (from his perspective, "How can you not know how to deal with a Grade 2 who's giving you a little bit of a problem?" 1. 995-1104; see Table 2, Frustration). He wondered, "[... what would it be like if] more people had more training [to work with high risk children and youth]." From these comments, we interpret Brian's efficacy for having a positive influence on youth and teaching methods extends into the future and beyond his classroom to the broader education system.

Engagement. The most explicit indication of Brian's engagement in teaching - the enjoyment or positive affect he experiences in the act of teaching - was his statement, "I like it" (1. 146). However, his enjoyment and satisfaction also were reflected in the anecdotes he told about his students. For example, Brian described how one student made a meal with ingredients he had at home. Paraphrasing the student, Brian said, "Yeah, I made chicken chow mien." And Brian said, "Oh nice. How'd you do that?" Brian went on to explain how the student recalled a similar cooking activity in the class and searched YouTube for a recipe and made it. Brian said, “... and the beauty is he took a picture ... showed it to us ... told us about it ... so the next week we bought the stuff and he made it for us [in school] ... it was good" (1. 529-556).

Brian also recounted a time when he was working at a homeless shelter for youth and ran into a youth he had worked with at a camp several years earlier.

This kid ended up coming [back to name of shelter when he was] 20, 21. And he [was a] homeless kid. And he sees me, and he's like, "Brian, come here. I want to show you something." He goes into his room and he's got a picture of [us] standing out on top of this ... hill. I was like, jeez, ... this kid has been homeless for however many years, and he's got a picture from this trip ... that was pretty cool (1. 709-718). 
Brian referred to both these examples during our discussion of how he measures his success. When asked if he is disappointed when it seems he is not or cannot make a difference, he responded, "No, because ...," referring to his experience working at the youth shelter and in other programs, “... some of those seeds that were planted earlier ... grew a couple of years later ... you never know" (1. 686-700). We interpret that Brian's engagement in teaching is sustained to a large extent by his sense that he is effective and making a difference. He also remained consistently optimistic, or hopeful, about the possibilities for his students, even when success was not immediate or obvious. Brian appeared to be able to set realistic expectations for himself and his students, and he is willing to recognize many forms of success.

Commitment. Brian's long-term commitment to the teaching profession and particularly to youth who are unsuccessful in the traditional school system was evident. At one point in the interview, one researcher commented, "It seems as though you always see yourself with this focus," (1. 165-166) and Brian responded, "Yeah, yeah" (1. 168). Several times during the interview, he mentioned that he might consider working with a younger age group, but believed he would always work with and advocate for youth, "I see myself sticking with ... youth ..." (1. 873-874). "... That's the reason I became a teacher ..." (1. 995-1033). "I want to be ... an advocate for at-risk youth ..." (1. 10641070). Brian was surprised when we cited statistics for teacher attrition in positions like his. In fact he countered, “... there's a lot of people that stick around ...” (1. 1068-1069)

\section{Well-Being Variables}

Stress and exhaustion. Brian's teaching position presents situations that many teachers and other professionals would characterize as stressful (e.g., working with youth who have complex learning, mental health, and addiction problems; collaborating with outside agencies to address the needs of these youth; and coping with a district mandate that is not always realistic for the students in his program). However, Brian does not perceive stress and exhaustion are part of his experience at work, at least not to the extent that his well-being is threatened. During our discussion of what challenges him in his work and how he copes with those challenges, he described a number of ways in which he copes adaptively with potential sources of stress, including, "Exercise ... that works for me" (1. 1113), and talking with close colleagues, primarily his teaching aide and a teacher from another alternative education program. He emphasized the need to let things go ("I've just always been able to turn it off ... I don't need to hold on to things ..." 1 . 1113-1127) and recognized his limitations ("You can't control everything ... that is not possible-[to fix everything]," 1. 1143-1154). In addition to being realistic and optimistic, we observed that Brian maintains a sense of humour about his situation. For example, when asked to describe the challenges inherent in his work, he said, "The youth," laughing as he said it because he realized he had spent much of the interview claiming the youth are why he is in this profession and what maintains his engagement in the profession. Similarly, after talking about his ability to [typically] "turn it off," he acknowledged that doesn't always work and joked, “... that's where the wine comes in ..." (1. 1113-1127). 
When asked if he ever experienced exhaustion, he said, "No," but indicated that he's had days when he's been "just down." In response to such days Brian would typically review his goals in order to keep his objectives clear and in perspective:

... We talk about goals all the time here ... the funny thing is you don't always practice what you preach, right? ... I've had where I haven't done my goals in ... six months or a year ... and then ... just having those goals ... OK, that's my focus again" (1. 1159-1167).

Brian also commented on "the constant repetition of situations" across students and families, "... that's one of the downfalls ...," which we interpreted as causing some feelings of exhaustion at times, but not enough for Brian to leave this work. Offering an explanation about why others may choose to leave this work, Brian said, “... the ones that leave are the ones that personalize everything ... they can't accept that they didn't make this change ... [or] they want a pat on the back ... on some level you all want it ... but some people need it" (1. 1090-1097).

Frustration. Although Brian revealed attitudes and actions associated with resilience, which should keep him motivated and healthy for facing challenging teaching conditions most of the time, he did express feelings of frustration about various aspects of his position. Frustration is defined in the literature as feelings of anger/annoyance when faced with interference to carry out tasks to the best of one's ability (Keenan \& Newton, 1982, as cited in Keenan \& Newton, 1984). Often considered to be an aspect of work stress, frustration is thought to involve behavioural and psychological responses similar to those associated with experiences of stress (Chen \& Spector, 1992). However, Keenan and Newton $(1982 ; 1984)$ identify an important distinction between stress and frustration. In their research, they found frustration was devoid of, and unrelated to, experiences of the anxiety associated with stress. In our study, Brian did not voice his experiences in terms of stress. When asked, "Does that [others having a limited understanding of the youth and programs needs] cause some [feelings of] stress and isolation?" (838-841), Brian replied, "No... I know where I'd like to take our program ... I know where I want to go, so I'm always kind of trying to figure out where- or how to get there" (1. 846849). Congruent with Keenan and Newton's (1982) findings and SDT (Vansteenkiste \& Ryan, 2013), Brian's expressions of frustration about others' lack of understanding about the needs of youth within his program and other aspects of his position (see examples below) did not appear to be a source of stress. Rather, they appeared to be a source of annoyance, related to temporary barriers to his feelings of autonomy, belonging, and competence, which he feels able to circumvent or rectify.

\section{Emergent Variables}

Frustration. To accurately represent the experiences of Brian, we differentiate between the constructs of stress and frustration, and propose frustration is a new category that merits analysis. Also, we note that the constructive ways in which Brian copes with frustration reflect an internal locus of causality (Deci \& Ryan, 1985a), which likely serves to bolster his motivation and health for teaching in his challenging context.

A significant frustration for Brian appears to be his belief that some of the youth who arrive in his program "don't need to be [there] ... if you just did a couple of things 
earlier, or didn't do a couple of things earlier ... they'd be better off' (1. 170-180). This frustration has led to his goal of working with youth at an earlier age, "giving them the tools ... so if they do get to this point they have more tools and they're a little more ready to move on or have bigger hopes and bigger dreams ..." (1. 170-180). Brian also expressed frustration about the lack of consistency in students' behaviour from day to day.

It's literally different day to day. Yesterday ... [we] got some good stuff going in the morning, and then there was no one here in the afternoon. And I was like, "Oh my God" ... it was frustrating to me. ... it can go from ... doing Science 10 one minute to having a big conversation and then, you know, calling a mental health car or something like that ... there's no consistency. Definitely no consistency (1. 239-257).

Moreover, “[we] don't get a choice of who comes here. You've got ... K who's got a 63 IQ and does drugs, but then you've got J over here who's in Grade 10, doing really well, but [has] all these other issues. And then, you've got someone else who's prostituting themselves on the street" (1. 441-450). The diverse and complex needs of students in Brian's program created an exceptionally challenging environment in which to accomplish both academic and social goals. Progress can appear slow or, at times, halting.

Brian's frustration at district expectations for him to address the multiple, complex needs of students was apparent when we asked him to describe the mandate of his program. Brian explained, "The district would describe one thing, and then the reality is another thing." He went on to explain that he feels some pressure to cover academics, but emphasized that, for many of these kids, “... academics are the least of [their] worries ... I should be dealing with their mental health stuff ... [and] basic living skills ... if we are to make any change in their lives" (1. 260-280). Brain's frustration appears to stem from a sense that "others," including other teachers, don't "get it" and the people who make decisions often are very "out of touch." For example, Brian described an experience he had at a professional development event in which a colleague spoke in front of the group: "I don't understand how you ... can have a program that the kids only come for three hours a day ... three days a week.... We just make our kids come." Brian did not respond at the time, but later called the teacher,

... after I had a chance to cool down, and I said, "That was your youth that you sent us," and I was not joking ... "that student is prostituting herself out on the street, and ... her coming to school the next day is a success ... when you kicked her out of your program because ... she wasn't fitting into your box" ... yeah ... so that's why I sometimes don't always connect with the other programs (1. 817-838).

Similarly, Brian described a second event in which a representative of the ministry was unveiling new education plans involving technology:

... and so in my head, I'm thinking, "Oh, this is great. You know, this will be great for my kids, ... my children" ... And then, I just raised my hand, and I said, "This works great for all the haves, this works awesome, but ... what about the have nots? What happens to these kids?" ... And [the ministry representative] goes, "Oh yeah, well, ... this isn't perfect" and "we're still working out some things." And I [thought], "You have no clue." ... they have no clue what they're going to do with 
[the youth in my program], and it'll just be a further barrier... this technology stuff $\ldots$ for them to be left behind (1. 860-873).

We interpret that Brian's experience of frustration over these and other issues is real and significant. However, Brian presented each of these examples in the context of discussing positive and proactive initiatives he envisions taking to improve the system and outcomes for youth (e.g., intervening early, training teachers, advocating for youth). Rather than letting frustration be a threat to his well-being, he appears to orientate toward internal supports for his motivation, which is another key characteristic of selfdetermined individuals (Deci \& Ryan, 1985a; Wehmeyer, 1999). Specifically, his response to frustration is acting in a way that supports his internal motivation-doing things that will make him feel autonomous and effective.

Hope. In addition to the new well-being variable, frustration, we propose a new motivational variable, hope, which is linked to psychological resilience, or maintaining or increasing one's competence in the face of adversity (Bobek, 2002). We define hope as Brian's ability to maintain a sense of optimism that he can promote positive outcomes for his students. He does this in two ways. First, Brian avoids hearing about aspects of students' private lives that would cause him to lose hope. To this end, Brian limits his contact with students' families; he said, "The unfortunate thing is sometimes when I see the family and I know about the family, it makes me feel less likely that there's going to be success because I'm just like, "Oh, my God. You've got no hope at all" (1.747-751). Similarly, Brian discourages students from sharing sensitive information about their private lives with him. When talking about maintaining positive, non-judgmental relationships with his students, Brian said he tells them, “Just don't tell me the details of what you're doing because then I have to report it" (1.227-228).

Second, Brian uses caution when defining student success. When asked how he measures student success, he responded, "You don't. You really don't. You measure it one thing at a time. ... It's based on each kid and you measure very small increments because if you try and measure it in big, you're going to never last" (1. 517-520). "It's not academic. ... I've got a young lady who's up in treatment now and it's amazing that she's up there. I mean, she was in terrible shape before and so, I'm like, 'That's a huge success" (1.565-570). Brian also maintains a long view of his students' lives: "You see them two years later ... and you're, like, 'Wow, this is great.' Some of those seeds that were planted earlier, you know, grew a couple of years later. You never know" (1. 696700).

\section{Relationships Between Self-Determination Variables and Motivation and Well-Being Outcome Variables}

Our analyses of Brian's interview transcript focused on whether and how Brian's sense of SD (i.e., autonomy, belonging, and competence) enhanced his teaching efficacy, engagement, and commitment and reduced his experience of stress and exhaustion. Although we did not use these labels in our interview questions, the content of Brian's responses to them (as in Table 2 above), provide evidence that these researcher-derived constructs can be valid representations of this teacher's experience in his classroom workplace. 
We interpret Brian's motivation for teaching is supported by his experiences of autonomy, belonging, and competence. For example, the flexibility his program provides allows Brian to structure activities and interpersonal interactions in a way that he believes best meets the needs of the students he serves. This autonomy likely promotes positive outcomes for students, and having a positive impact on the lives of students is a primary criterion by which Brian measures his own success (efficacy). Brian's feelings of autonomy also enable him to define success on an individual basis ("based on each kid ... very small increments"), which may protect his efficacy from traditional accountability pressures he and his students may not be able to meet ("academics are the least of these kids' worries"). Brian's responses to our questions indicate his sense of belonging is supported primarily through his relationships with students, and these relationships are a source of efficacy ("I firmly believe you can make a connection ... I do this with all my youth") and engagement (speaking about the youth who kept the picture from camp, "That was pretty cool"). Interestingly, we interpret that not having relationships with parents protects his efficacy concerning the youth ("knowing the family makes me feel less likely there's going to be success"), and potential for bias. Finally, Brian's sense of competence from past experience fosters an expectation that he will be successful in the future (efficacy), and this contributes to engagement ("I'm good at it, and I like it") and commitment ("a lot of people stick around because you get to build up these relationships with kids and staff").

Similarly, we hypothesize that Brian's experience of autonomy, belonging, and competence protect him from experiencing stress and exhaustion. For example, although Brian expressed struggling to connect with many of his teaching colleagues in both mainstream and alternative contexts ("they don't understand how I do my job, I don't understand how they do their job"), he relies on the "good" relationships he has with his teaching aide ("we call each other our work husband") and another teacher in a similar program ("we'll sometimes chat") when he has a "crappy day." Also, the level of autonomy his program provides frees him from traditional measures of accountability ("I don't follow the same rules as everyone else does"), which could create significant stress in a program such as his where students would struggle to meet the traditional goals of school. Importantly, Brian appears to operate with an internal locus of causality. His strong internal motivation allows him to confidently and effectively find solutions (e.g., early intervention, training teachers, advocating for youth) to address the needs of youth. Also, he articulates future-oriented goals to bring about change within the educational system. In this way, although he experiences some barriers to his motivational needs, he does not perceive he is a pawn in a large organization; rather he is an autonomous individual who is capable of promoting positive outcomes for himself and his students.

\section{Summary and Conclusions}

One purpose of our larger program of research is to examine how some teachers thrive in teaching positions others consider extremely challenging and stressful. In this article we examined this issue from a motivation and well-being perspective using a case study to analyze one teacher's experiences of these constructs. Specifically, we asked whether and how one teacher's sense of SD (autonomy, belonging, and competence) supported other aspects of his motivation (efficacy, engagement, and commitment) and 
well-being (adaptive responses to situations that are stressful and could lead to emotional exhaustion).

Our interview with Brian was part of a larger case study of an alternative education program that enrolls youth who have struggled in mainstream education. Previous aspects of this case study led us to conclude that our research goal-identifying what it is that teachers say and do to facilitate at-risk students' SD and engagement in school-might require the examination of supports and barriers for teachers' motivation and well-being too. Specifically, we chose to examine whether and how the fulfillment of teachers' SD needs relates to their motivation, well-being, and performance. In order to begin to investigate these relationships, we developed an interview protocol that draws on conceptual categories from previous research, but enables teachers to first articulate their experience of motivation in their own words.

We found ample content in Brian's interview to link with our pre-conceived categories, suggesting these researcher-derived constructs can be authentic representations of his professional experience and particularly of his work with youth. For example, Brian expressed high efficacy for and engagement in teaching. He perceived this is the right profession for him and predicted he will continue to work with and for struggling youth in the future (commitment), but possibly in settings where he can intervene on behalf of children and youth earlier and help teachers to develop knowledge and skills to better address the needs of students who face significant barriers to success. Also, he described a number of personal qualities and social supports we interpret are protective factors for stress and exhaustion (e.g., being able to let go, having realistic expectations for the youth and himself, getting support from key colleagues on "crappy days").

Although Brian did not refer to challenging aspects of his job as "stressors," he acknowledged numerous frustrations, always in the context of describing ideas and initiatives he has for improving the situation for youth and for himself. We infer that Brian has an internal locus of causality, which is a characteristic of individuals who are self-determined (Deci \& Ryan, 1985a,1985b; Wehmeyer, 1999). Locus of causality refers to the extent people perceive their actions to be internal or externally motivated (Turban, Tan, Brown, \& Sheldon, 2007). People who report high levels of internal motivation are more likely to effectively self-regulate their behavior; cope with aspects of their environments that frustrate or hinder fulfillment of their needs for autonomy, belonging, and competence (Vansteenkiste \& Ryan, 2013); and experience improved performance and task enjoyment (Turban et al, 2007). This research suggests people with an internal locus of causality may be more likely to act in ways that decrease their feelings of frustration. For these reasons, we added frustration as a new, emergent category in our coding scheme.

People's perceived feelings of internal motivation have been found to moderate their experiences of stress (Trépanier, Fernet, \& Austin, 2013). Consistent with these and other findings from SDT (Turban et al., 2007; Vansteenkiste \& Ryan, 2013), it is likely that Brian's internal locus of causality led to his responding adaptively to challenging situations (e.g., seek social supports, approach tasks with a sense of competence). For these reasons we believe Brian may have been shielded from feelings of anxiety 
associated with stress and withdrawal, experiencing instead temporary feelings frustration that appeared to drive him to instigate change within the educational system. Consistent with this interpretation, Brian frequently mentioned experiences of autonomy, belonging, and competence in his descriptions of what helps him feel effective and efficacious, stay engaged, and cope with frustrations at work.

We also found that Brian employs adaptive tactics to maintain his sense of optimism, or hope, that he can promote positive outcomes for his students. He avoids hearing about events in his students' private lives over which he has little control and that could threaten his optimism. Brian also uses caution when measuring his students' success. For example, he measures student success on an individual basis and in very small increments, while also taking a long view of his students' lives.

Given the high rate of teacher attrition in some areas of education (e.g., low SES urban and rural schools, special education settings, and especially settings that include youth characterized as emotionally and behaviourally disturbed; see Billingsley, 2004), research that seeks to understand how some teachers thrive in these contexts is warranted. Our research examines links between sources of support for teachers' motivation and well-being, which may in turn influence their retention and effectiveness. This research suggests contexts that support teachers' self-determined motivation may be one place to learn how to sustain and retain teachers. Also, our case study approach to studying teacher motivation and well-being is unique, but appears to hold promise for advancing theory and research in several ways. Much of the research on teacher motivation (including self-determination) and well-being relies on survey self-report questionnaires, which are limited in their ability to promote in-depth understandings of complex phenomena in situ. The use of open-ended interview questions that encourage teachers to express their experiences of theoretical constructs in their own words allows for a more thorough understanding of how constructs are perceived by teachers and manifest in their lives. Importantly, in describing and identifying constructs in need of further investigation (e.g., perceived experiences of frustration), teachers serve as contributors to, as well as sources for, data within our research process. Linking teachers' descriptions to researcher-derived constructs enhances the validity of our interpretations. Finally, to our knowledge, our study is the first to investigate the relationships between teachers' sources of motivation and well-being within alternative education settings.

It is important to note this study's limitations. First, our findings are preliminary and rely on a single, very specialized case study conducted within one classroom. However, working in Brian's classroom enabled us to develop and test our research protocols. Our plan for the future includes expanding our data collection to include more and varied alternative education programs. The results of this work should be particularly instrumental for teachers working in alternative educational settings who may experience abnormally challenging student and environmental conditions. Secondly, we have drawn on SDT, which our findings indicate is appropriate, but other theories may be appropriate, too. For example, we are drawn to descriptions of "resilient" teachers who operate through a sense of agency, are able to adapt to varied and challenging working conditions, derive deep joy and personal satisfaction from their work, and continually seek ways (e.g., through professional development) to improve their teaching (Castro et al., 2010; Gu \& Day, 2007; Stanford, 2001; Williams, 2003). Perspectives on resilience 
distinguish between risk and protective factors and articulate a number of personal qualities (e.g., self-efficacy, self-mastery, resourcefulness, health) and social supports (e.g., friends, family, the community) that help teachers work successfully in challenging environments and appear to be closely associated with our current findings (Rutter, 1979, 1985, as cited in Richardson, 2012). For the past several decades the field of resiliency research has expanded from identifying and defining risk and protective factors, to an examination of internal motivational forces and contextual experiences that serve to support individuals' optimal functioning in challenging contexts (Richardson, 2012). Therefore, alignment of findings from the fields of SD, teacher resiliency, and well-being is a timely, logical progression for our research.

\section{References}

Bandura, A. (1997). Self-efficacy: The exercise of control. New York, NY: Freeman.

Battin-Pearson, S., Newcomb, M. D., Abbott, R. D., Hill, K. G., Catalano, R. F., \& Hawkins, J. D. (2000). Predictors of early high school dropout: A test of five theories. Journal of Educational Psychology, 92(3), 568-582.

Billingsley, B. S. (2004). Special education teachers' retention and attrition: A critical analysis of the research literature. Journal of Special Education, 38, 39-55.

Billingsley, B. S., \& Cross, L. H. (1992). Predictors of commitment, job satisfaction, and intent to stay in teaching: A comparison of general and special educators. Journal of Special Education, 25, $453-471$.

Block, J. H., \& Block, J. (1980). The role of ego-control and ego-resiliency in the origination of behavior. In W. A. Collings (Ed.), The Minnesota symposia on child psychology (vol. 13, pp. 39-101). Hillsdale, NJ: Erlbaum.

Bobek, B. L. (2002). Teacher resiliency. The Clearing House, 75(4), 202-205.

Brophy, J. (2004). Motivating students to learn. Hillside, NJ: Erlbaum.

Butler, D. L. (2011). Investigating self-regulated learning using in-depth case studies. In B. Zimmerman \& D. Schunk (Eds.), Handbook of self-regulation of learning and performance (pp. 346-360). New York, NY: Routledge.

Canrinus, E. T., Helms-Lorenz, M., Beijaard, D., Buitink, J., \& Hofman, A. (2012). Self-efficacy, job satisfaction, motivation and commitment: Exploring the relationships between indicators of teachers' professional identity. European Journal of Psychology of Education, 27, 115-132. doi:10.1007/s10212-011-0069-2

Castro, A. J., Kelly, J., \& Shih, M. (2010). Resilience strategies for new teachers in high-needs areas. Teaching and Teacher Education, 26, 622-629.

Chan, W. Y., Lau, S., Nie, Y., Lim, S., \& Hogan, D. (2008). Organizational and personal predictors of teacher commitment: The mediating role of teacher efficacy and identification with school. American Educational Research Journal, 45, 597-630.

Chang, M. L. (2009). An appraisal perspective of teacher burnout: Examining the emotional work of teachers. Educational Psychology Review, 21, 193-218.

Chaplain, R. P. (2008). Stress and psychological distress among trainee secondary teachers in England. Educational Psychology: An International Journal of Experimental Educational Psychology, 28, 195-209. 
Chen, P. Y., \& Spector P. E. (1992). Relationships of work stressors with aggression, withdrawal, theft and substance use: An exploratory study. Journal of Occupational and Organizational Psychology, 65, 177-184.

Cho, Y., \& Shim, S. S. (2013). Predicting teachers' achievement goals for teaching: The role of perceived school goal structure and teachers' sense of efficacy. Teaching and Teacher Education, 32, 12-21. doi:10.1016/j.tate.2012.12.003

Christenson, S. L., \& Thurlow, M. L. (2004). School dropouts: Prevention considerations, interventions, and challenges. Current Directions in Psychological Science, 13(1), 36-39.

Collie, R. J., Shapka, J. D., \& Perry, N. E. (2012). School climate and social-emotional learning: Predicting teacher stress, job satisfaction, and teaching efficacy. Journal of Educational Psychology, 104(4), 1189-1204. doi:10.1037/a0029356

Darling-Hammond, L. (2003). Keeping good teachers: Why it matters, what leaders can do. Educational Leadership, 60(8), 6-13.

Deci, E. L., Eghrari, H., Patrick, B. C., \& Leone, D. R. (1994). Facilitating internalization: The selfdetermination theory perspective. Journal of Personality, 62(1), 119-142.

Deci, E. L., \& Ryan, R. M. (1985a). The general causality orientations scale: Self-determination in personality. Journal of Research in Personality, 19, 109-134.

Deci, E.L., \& Ryan, R.M. (1985b). Intrinsic motivation and self-determination in human behavior. New York, NY: Plenum Press.

Deci, E. L., \& Ryan, R. M. (1991). A motivational approach to self: Integration in personality. In R. A. Dienstbier \& R. A. Dienstbier (Eds.), Nebraska symposium on motivation, 1990: Perspectives on motivation (pp. 237-288). Lincoln, NE: University of Nebraska Press.

Deci, E. L., \& Ryan, R. M. (2002). Overview of self-determination theory: An organismic-dialectical perspective. In E. L. Deci \& R. M. Ryan (Eds.), Handbook of self-determination research. (pp. 3-33). Rochester, NY: University of Rochester Press.

Deci, E. L., Ryan, R. M., Gagné, M., Leone, D. R., Usunov, J., \& Kornazheva, B. P. (2001). Need satisfaction, motivation, and well-being in the work organizations of a former eastern bloc country: A cross-cultural study of self-determination. Personality and Social Psychology Bulletin, 27(8), 930-942. doi:10.1177/0146167201278002

Denzin, N. K., \& Lincoln, Y. S. (Eds.). (2005). The Sage handbook of qualitative research. Thousand Oaks, CA: Sage.

Duckworth, A. L., Quinn, P. D., \& Seligman, M. E. P. (2009). Positive predictors of teacher effectiveness. Journal of Positive Psychology, 4, 540-547.

Duffy, G. G. (1997). Powerful models or powerful teachers? An argument for teacher-as-entrepreneur. In S. A. Stahl \& D. A. Hayes (Eds.), Instructional models in reading (pp. 351-365). Mahwah, NJ: Erlbaum.

Gersten, R., Keating, T., Yovanoff, P., \& Harniss, M. K. (2001). Working in special education: Factors that enhance special educators' intent to stay. Exceptional Children, 67(4). 549-567.

Gibbert, M., Ruigrok, W., \& Wicki, B. (2008). What passes as a rigorous case study? Strategic Management Journal, 29(13), 1465-1474.

Grawitch, M. J., Trares, S., \& Kohler, J. M. (2007). Healthy workplace practices and employee outcomes. International Journal of Stress Management, 14(3), 275-293.

Grolnick, W., Gurland, S., Jacob, J., \& Decourcey, W. (2002). The development of self-determination in middle childhood and adolescence. In A. Wigfield \& J. Eccles (Eds.), Development of achievement motivation (pp. 148-171). San Diego, CA: Academic Press. 
Gu, Q., \& Day, C. (2007). Teachers' resilience: A necessary condition for effectiveness. Teaching and Teacher Education, 23, 1302-1316.

Hakanen, J., Bakker, A. B., \& Schaufeli, W. B. (2006). Burnout and work engagement among teachers. Journal of School Psychology, 43, 495-513.

Henry, K. L., Knight, K. E., \& Thornberry, T. P. (2012). School disengagement as a predictor of dropout, delinquency, and problem substance use during adolescence and early adulthood. Journal of Youth and Adolescence, 41(2), 156-166.

Hofer G., \& Perry, N. E. (2012, April). Using observational and photo elicitation to study selfdetermination in youth in an alternative education program. Paper presented at the meeting of the American Education Research Association (AERA), Vancouver, BC.

Ilardi, B. C., Leone, D., Kasser, T., \& Ryan, R. M. (1993). Employee and supervisor ratings of motivation: Main effects and discrepancies associated with job satisfaction and adjustment in a factory setting. Journal of Applied Social Psychology, 23, 1789-1805. doi:10.1111/j.15591816.1993.tb01066.x

Jennings, P. A., \& Greenberg, M. T. (2009). The prosocial classroom: Teacher social and emotional competence in relation to student and classroom outcomes. Review of Educational Research, 79, 491-525.

Jepson, E., \& Forrest, S. (2006). Individual contributory factors in teacher stress: The role of achievement striving and occupational commitment. British Journal of Educational Psychology, 76, 183-197.

Keenan, A. A., \& Newton, T. J. (1982). Stressful incidents, stressors, and psychological strain in young professional engineers. Unpublished manuscript.

Keenan, A. A., \& Newton, T. J. (1984). Frustration in organizations: Relationships to role stress, climate, and psychological strain. Journal of Occupational Psychology, 57(1), 57-65.

Klassen, R. M., Bong, M., Usher, E. L., Chong, W. H., Huan, V. S., Wong, I. Y., \& Georgiou, T. (2009). Exploring the validity of the Teachers' Self-Efficacy Scale in five countries. Contemporary Educational Psychology, 34, 67-76.

Klassen, R. M., \& Chiu, M. M. (2010). Effects on teachers' self-efficacy and job satisfaction: Teacher gender, years of experience, and job stress. Journal of Educational Psychology, 102, 741756. doi:10.1037/a0019237

Klassen, R. M., \& Chiu, M. M. (2011). The occupational commitment and intention to quit of practicing and pre-service teachers: Influence of self-efficacy, job stress, and teaching context. Contemporary Educational Psychology, 36(2), 114-129.

Klassen, R. M., Perry, N. E., \& Frenzel, A. C. (2012). Teachers' relatedness with students: An underemphasized component of teachers' basic psychological needs. Journal of Educational Psychology, 104, 150-165.

Klassen, R. M., Tze, V., Betts, S. M., \& Gordon, K. A. (2011). Teacher efficacy research 1998-2009: Signs of progress or unfulfilled promise? Educational Psychology Review, 23(1), 21-43.

Klusmann, U., Kunter, M., Trautwein, U., Lüdtke, O., \& Baumert, J. (2008). Teachers' occupational well-being and quality of instruction: The important role of self-regulatory patterns. Journal of Educational Psychology, 100, 702-715.

Kyriacou, C. (2001). Teacher stress: Directions for future research. Educational Review, 53, 27-35.

Lynch, M. F. J., Plant, R. W., \& Ryan, R. M. (2005). Psychological needs and threat to safety: Implications for staff and patients in a psychiatric hospital for youth. Professional Psychology: Research and Practice, 36(4), 415-425. doi:10.1037/0735-7028.36.4.415 
Maslach, C., \& Jackson, S. E. (1981). The measurement of experienced burnout. Journal of Occupational Behavior, 2, 99-113.

Matheny, K. B., Gfroerer, C. A., \& Harris, K. (2000). Work stress, burnout, and coping at the turn of the century: An Adlerian perspective. Journal of Individual Psychology, 56(1), 74-87.

McCarthy, C. J., Lambert, R. C., O’Donnell, M., \& Melendres, L. T. (2009). The relation of elementary teachers' experience, stress, and coping resources to burnout symptoms. Elementary School Journal, 109(3), 282-300.

McLeskey, J., Tyler, N. C., \& Flippin, S. S. (2004). The supply of and demand for special education teachers: A review of research regarding the chronic shortage of special education teachers. Journal of Special Education, 38, 5-21.

Nieto, S. (2009). From surviving to thriving. Educational Leadership, 66(5), 8-13.

Parker, S. L., Jimmieson, N. L., \& Amiot, C. E. (2013). Self-determination, control, and reactions to changes in workload: A work simulation. Journal of Occupational Health Psychology, 18(2), 173-190.

Richardson, G. E. (2012). Metatheory of resilience and resiliency. Journal of clinical Psychology, $58(3), 307-321$.

Ross, J. A., Hogaboam-Gray, A., \& Hannay, L. (2001). Effects of teacher efficacy on computer skills and computer cognitions of K-3 students. Elementary School Journal, 102, 141-156.

Roth, G., Assor, A., Kanat-Maymon, Y., \& Kaplan, H. (2007). Autonomous motivation for teaching: How self-determined teaching may lead to self-determined learning. Journal of Educational Psychology, 99, 761-774.

Ryan, R. M., \& Deci, E. L. (2000). Self-determination theory and the facilitation of intrinsic motivation, social development and well-being. American Psychologist, 55, 68-78.

Ryan, R. M., \& Deci, E. L. (2002). An overview of self-determination theory: An organismic dialectical perspective. In E. L. Deci \& R. M. Ryan (Eds.), Handbook of self-determination research (pp. 3-33). Rochester, NY: University of Rochester Press.

Ryan, R. M., \& Deci, E. L. (2011). A self-determination theory perspective on social, institutional, cultural, and economic supports for autonomy and their importance for well-being. In V. I. Chirkov, R. M. Ryan, \& K. M. Sheldon (Eds.), Human anatomy in cross-cultural context: Perspectives on the psychology of agency, freedom, and well-being (pp. 45-64). New York, NY: Springer.

Schaufeli, W. B., \& Bakker, A. B. (2004). Job demands, job resources, and their relationship with burnout and engagement: A multi-sample study. Journal of Organizational Behavior, 25(3), 293-315. doi:10.1002/job.248

Schaufeli, W. B., Bakker, A. B., \& Salanova, M. (2006). The measurement of work engagement with a brief questionnaire: A cross-national study. Educational and Psychological Measurement, 66, 701-716.

Sheldon, K. M., Ryan, R., \& Reis, H. (1996). What makes for a good day? Competence and autonomy in the day and in the person. Society for Personality and Social Psychology, 22(12), 12701279 .

Stanford, B. H. (2001). Reflections of resilient, persevering urban teachers. Teacher Education Quarterly, 28, 75-87.

Strauss, A., \& Corbin, J. (1994). Grounded theory methodology. In N. K. Denzin \& Y. S. Lincoln (Eds.), Handbook of qualitative research (pp. 273-285). Thousand Oaks, CA: Sage. 
Taylor, I. M., \& Ntoumanis, N. (2007). Teacher motivational strategies and student self-determination in physical education. Journal of Educational Psychology, 99, 747-760.

Taylor, I. M., Ntoumanis, N., \& Standage, M. (2008). A self-determination theory approach to understanding the antecedents of teachers' motivational strategies in physical education. Journal of Sport and Exercise Psychology, 30, 75-94.

Tickle, B. R., Chang, M., \& Kim, S. (2011). Administrative support and its mediating effect on US public school teachers. Teaching and Teacher Education, 27(2), 342-349.

Turban, D. B., Tan, H. H., Brown, K. G., \& Sheldon, K. M. (2007). Antecedents and outcomes of perceived locus of causality: An application of self-determination theory. Journal of Applied Social Psychology, 37(10), 2376-2404.

Trépanier, S. G., Fernet, C., \& Austin, S. (2013). The moderating role of autonomous motivation in the job demands-strain relation: A two sample study. Motivation and Emotion, 37(1), 93-105.

Tschannen-Moran, M., \& Woolfolk Hoy, A. (2001). Teacher efficacy: Capturing an elusive construct. Teaching and Teacher Education, 17, 783-805.

Urdan, T., \& Turner, J. C. (2005). Competence motivation in the classroom. In A. J. Elliot \& C. S. Dweck (Eds.), Handbook of competence and motivation (pp. 297-317). New York, NY: The Guildford Press.

Vansteenkiste, M., \& Ryan, R. M. (2013). On psychological growth and vulnerability: Basic psychological need satisfaction and need frustration as a unifying principle. Journal of Psychotherapy Integration, 23(3), 263-280.

Van den Broeck, A., Vansteenkiste, M., De Witte, H., \& Lens, W. (2008). Explaining the relationships between job characteristics, burnout, and engagement: The role of basic psychological need satisfaction. Work \& Stress, 22(3), 277-294.

Van Petegem, S., Beyers, W., Vansteenkiste, M., \& Soenens, B. (2012). On the association between adolescent autonomy and psychosocial functioning: Examining decisional independence from a self-determination theory perspective. Developmental Psychology, 48(1), 76-88.

Wehmeyer, M. L. (1999). A functional model of self-determination: Describing development and implementing instruction. Focus on Autism \& Other Developmental Disabilities, 14, 53-62.

Williams, J. S. (2003). Why great teachers stay. Educational Leadership, 60(8), 71-75.

Woolfolk Hoy, A., \& Davis, H. A. (2006).Teacher self-efficacy and its influence on the achievement of adolescents. In F. Pajares \& T. Urdan (Eds.), Self-efficacy of adolescents, (pp. 117-137). Greenwich, CT: Information Age Publishing.

Yin, R. K. (2003). Case study research: Design and methods (3rd ed.). Thousand Oaks, CA: Sage.

\section{Authors' Note}

Correspondence concerning this article should be addressed to Nancy E. Perry, Department of Educational and Counselling Psychology, and Special Education, Faculty of Education, 2125 Main Mall, Vancouver, BC, V6T 1Z4, Canada. Email: nancy.perry@ubc.ca 